\title{
Uwagi o uniwersalnym i narodowym charakterze rewolucji
}

W optyce historyka idei istnieją pojęcia, o które w swojej pracy potyka się co chwila, pojęcia, które są mu znane i które przy okazji realizacji różnych zadań badawczych mu towarzyszyły, a jednocześnie pojęcia owe traktowane jako samodzielne byty stają się dyskusyjne, wymagające wielu uściśleń, rozstrzygnięć i, co najważniejsze, tracące pierwotny walor oczywistości.

Do słów tych należy, w naszej ocenie, termin: „rewolucja”. Badacze zjawiska kryjącego się pod tym pojęciem są na ogół zgodni, iż termin wywodzi się z astronomii i swoją popularność zawdzięcza Mikołajowi Kopernikowi, który zatytułował swoje dzieło: De revolutionibus orbium coelestium ${ }^{1}$. Owa przyrodnicza etymologia staje się jednocześnie podstawą późniejszych sporów $o$ istotę i naturę rewolucji. Hipotezy i tworzone do dnia dzisiejszego teorie muszą zmierzyć się z kilkoma powiązanymi ze sobą kwestiami: czy rewolucja jest procesem naturalnym, czy może wyjątkiem od reguły? Czy tak jak ruch gwiazd jest niezależny od woli człowieka, występujący w pewnych cyklach, tak rewolucje muszą wystąpić, gdyż warunkuje je nadludzka konieczność? Naturalność rewolucji oznaczać musi ich etyczną neutralność, podobnie zresztą jak towarzyszący im karnawał przemocy.

\footnotetext{
${ }^{1}$ H. Arendt: $O$ rewolucji. Przeł. M. Godyń. Kraków 1991, s. 40 i nast.
} 
Na potrzeby niniejszego artykułu przyjmiemy następujące, bardzo ogólne, rozumienie rewolucji, mając świadomość, że jest ono pewną kompilacją powszechnie znanych definicji - radykalna, szybka zmiana społeczna ${ }^{2}$. Zatem w każdej rewolucji będziemy mieć do czynienia z 3 elementami koniecznymi: nowością, początkiem i przemocą.

Po tym ogólnym wprowadzeniu musimy powrócić do myśli wyrażonej w pierwszym zdaniu. Każdy wie, czym jest rewolucja. Mając podstawową wiedzę o rewolucji francuskiej (1789) czy radzieckiej (1917), jesteśmy w stanie stworzyć zarówno definicję, jak i uproszczone modele procesów rewolucyjnych. Jednakże dla historyka idei istota problemu leży gdzie indziej. Pytania i odpowiedzi udzielane przez socjologów czy historyków stają się jedynie punktem wyjścia. Co ważne, w historii idei nakładają się na siebie i wzajemnie warunkują fakty historyczne i idee, brakuje nam natomiast miarodajnego narzędzia pozwalającego je rozgraniczyć, ocenić, na ile czyjaś myśl, poglądy wpłynęły na bieg wydarzeń, lub odwrotnie. Co więcej, dla historyka idei stosowany w literaturze przedmiotu podział na rewolucje polityczne i rewolucje społeczne nie ma znaczenia, gdyż obydwa typy znajdują się potencjalnie w orbicie jego zainteresowań. Ponadto historyk idei jest skazany również na analizę potocznych rozumień rewolucji, którym często daleko do naukowej precyzji. Bada zatem kategorie zjawisk bliskie rewolucji, ale $\mathrm{w}$ istocie niekoniecznie nią będące wojny domowe, żakerie, zamachy stanu, rewolty chłopskie, bunty, secesje itp.

Kolejnym problemem, być może o charakterze fundamentalnym, jest fakt, że historyk idei bada przejawy ludzkiej myśli, a ta z istoty swojej jest zindywidualizowana. Badamy zatem myśl Karola Marksa, Alexisa de Tocqueville'a, Edmunda Burke'a, Włodzimierza Lenina czy Lwa Trockiego. Fakt, że badamy czasem grupy poglądów, szkoły, programy partii politycznych czy stowarzyszeń, niczego w istocie nie zmienia. Problem bowiem zasadza się na fakcie, że rewolucja zakłada masowość, a ta wymyka się naszym narzędziom badawczym. Możemy analizować myśl Maksymiliana Robespierre'a (chociaż źródeł bezpośrednich mamy mało) i porównywać ją z poglądami George'a Dantona. Możemy przeanalizować poglądy jakobinów i żyrondystów, ale nie możemy tego uczynić z ludem Paryża czy Francuzami. Ogólna kategoria „niezadowolenia społecznego” czy „wrzenia rewolucyjnego" jest w tym wypadku niewystarczająca, chociaż mamy świadomość, że „nóż gilotyny ostrzy się w cieniu” i wiele czynników wiodących do społecznego wybuchu daje się uchwycić3. Cecha masowości sprawia, że ilość przechodzi w jakość i nie jest prostą wypadkową tworzących ją składników. Uruchomiona machina rewolucji zawsze jest zaskoczeniem nawet

\footnotetext{
${ }^{2}$ Por. W. Czajkowski: O pewnych poznawczych pożytkach płynacych z wieloznaczności słowa „rewolucja”. W: O rewolucji. Obrazy radykalnej zmiany spolecznej. Red. K. Brzechczyn, M. Nowak. Poznań 2007, s. 14-25.

${ }^{3}$ Zob. V. Pareto: Uczucia i działania. Fragmenty socjologiczne. Przeł. M. Dobrowolska, M. Rozpędowska, A. Zinserling, wybór, wstęp i red. A. Kojder. Warszawa 1994, s. 57 i nast.
} 
dla jej twórców i teoretyków. Stwierdzenia powyższe korespondują z uwagami Tocqueville’a, który pisał o rewolucji: ,[...] rozbijając z niesłychaną siłą granice państwowe, burząc trony, ujarzmiając ludy, a jednak mimo wszystko pociągając je ku sobie. Teraz to, co wydawało się zwykłym przypadkiem w życiu ludów, przedstawia się działaczom państwowym jako coś nowego, niezwykłego, a zarazem powszechnego, potwornego i niezrozumiałego, wobec czego myśl ludzka zatrzymuje się w zdumieniu. Jedni sądzą, że potęga ta nieznana doprowadzi społeczeństwo do zupełnego rozkładu. [...] Dla innych jest ona zjawiskiem opatrznościowem, mającem stworzyć nową ludzkość"4.

Wiek XX nieco masowość oswoił, co nie oznacza, że ją „cywilizował”. W wydanej pod koniec XIX w. pracy Gustaw Le Bon wieszczył: „Na gruzach tylu poglądów, niegdyś prawdziwych i czczonych, dziś już na półobumarłych, tylu powag zdruzgotanych przez rewolucje wyrosła na razie tylko ta jedna potęga, która dąży do pochłonięcia wszystkich innych w możliwie najkrótszym czasie. Obecnie, kiedy chwieją się, giną nasze odwieczne poglądy, kiedy usuwane są dotychczasowe podpory życia społecznego, urok potęgi tłumu wciąż rośnie i nic jej nie grozi. Nadchodzące stulecie będzie zatem erą tłumów"s. Oczywiście można stosować dystynkcje masowości i masowości rewolucyjnej, jednakże ich główne cechy są ze sobą zbieżne. W wydanej kilkadziesiąt lat wcześniej pracy (1859) John Stuart Mill dokonywał analizy masowości z perspektyw liberalnego indywidualizmu, jednakże jego oceny pozostają trafne, gdy odniesiemy je do rewolucji. Pisał: „Dzisiaj jednostka gubi się w tłumie. W polityce powiedzenie, że opinia publiczna dzisiaj rządzi światem, jest prawie komunałem. Jedyną siłą dzisiaj zasługującą na tę nazwę jest siła mas. [...] masy — to znaczy zbiorowa miernota. Większą jeszcze nowością jest fakt, że masy nie przejmują teraz swoich opinii od dygnitarzy Kościoła lub państwa, od ludzi uchodzących za przywódców lub z książek. Myślą za nich podobni im ludzie [...]”6.

Warto w tym momencie zastrzec, że relacjonowana cecha masowości ma dla nas wymiar neutralny, pochylamy się nad pewnym faktem bez jego wartościowania. Przywoływany już wcześniej de Tocqueville, analizując mechanizmy demokratyczne w Ameryce, widział w panowaniu większości zarówno rozum powszechny, jak i zagrożenie: ,[...] wielu ludzi zgromadzonych razem posiada więcej wykształcenia i rozumu niż jeden człowiek, że liczba prawodawców jest ważniejsza niż ich dobór. Tak wygląda idea równości zastosowana do rozumu ludzkiego. Teoria ta odbiera człowiekowi ostatni azyl, jakim jest godność rozumu"7.

${ }^{4}$ A. de Tocqueville: Dawne rzady i rewolucja. Przekł. W.M. Kozłowski. Warszawa 2003, s. 13.

${ }^{5}$ G. Le Bon: Psychologia tłumu. Tłum. B. Kaprocki. Kęty 2013, s. 14.

6 J.S. Mill: Utylitaryzm. O wolności. Wstęp T. Kotarbiński. Kraków 1959, s. 122.

7 A. de Tocqueville: O demokracji w Ameryce. Przeł. M. Król, wstęp J. Baszkiewicz. Warszawa 1976, s. 190. 
Problem masowości rewolucji jest dla historyka idei istotny z jeszcze jednego powodu, mającego bezpośredni związek z tytułem artykułu. Masowość nadaje rewolucji wymiar uniwersalny. Jak pisał Tocqueville: „Rewolucja francuska nie miała określonego terytorium; nie dość na tem, jednym z jej wyników był ten, że zatarła ona wszystkie dawne granice państwowe"8. Jednakże, jak było to już pośrednio sygnalizowane, rzecz nie dotyczy, ile osób weźmie w danej rewolucji udział, ale ile uwierzy w jej ideały. Zjawisko to jest o tyle skomplikowane, że mamy do czynienia z procesem tyle finezyjnym co długotrwałym (sic!). Widzimy w tym miejscu paradoks, gdyż sama rewolucja, będąc również procesem, a nie wydarzeniem, ze swej natury jest szybka. Możemy toczyć spór czy mówimy o roku, czterech latach czy dziesięciu, jakie są cezury początku i końca, ale co do zasady rewolucja nie może być ewolucją. Z kolei istotą recepcji idei jest ich długie trwanie. Jeśli spojrzymy na hasło rewolucji francuskiej: „Wolność, Równość, Braterstwo albo Śmierć" przyjęte po kilkudziesięciu latach jako dewiza Republiki Francuskiej już bez złowrogiego zakończenia, to zauważymy, jak długa i zawiła była historia przenikania wyrażonych idei do życia głoszących je ludzi. Braterstwo nigdy nie wyszło poza puste deklaracje, zaś o ideę wolności w różnych jej aspektach walczono przez kolejne kilkaset lat. Jak stwierdzał w jednym ze swoich przemówień Vaclav Havel, skądinąd przywódca i ideolog jednej z paradoksalnych XX-wiecznych ,aksamitnych” rewolucji, ,[...] takich wartości, jak obywatelska świadomość i samoświadomość, odpowiedzialność, wiara we własne siły czy zrozumienie ceny wolności - i wszystkich jej konsekwencji - nie da się wprowadzić czy ogłosić jednorazowym aktem. Rodzą się one długo i mozolnie, każdy musi ich poszukiwać w sobie i w sobie je odnajdywać. Są efektem wieloletniego procesu egzystencjalnego i społecznego, w którym ludzie wyzbywają się dawnych przyzwyczajeń i orientacji życiowych, a przyswajają sobie nowe"

Pisząc o rewolucji i ideach, musimy być wyczuleni, aby w naturalny sposób nie przekroczyć cienkiej granicy, o której już marginalnie wspomnieliśmy. Jest rzeczą oczywistą, że wśród czynników wywołujących rewolucję znajdują się określone idee. To, jak je zdefiniujemy, nie ma w tym momencie większego znaczenia. Roboczo, za Janem Baszkiewiczem, możemy uznać, iż na projekt rewolucyjny składają się pewne wyobrażenia ${ }^{10}$. Nie sposób jednakże miarodajnie ocenić, jaki jest ich potencjał. Rewolucja bolszewicka to oczywiście filozofia Marksa, ale również anarchizm, nihilizm, Hercen i Dostojewski, przykłady można mnożyć. Można wskazywać na różne ideowe przygotowanie wykształconych liberalnych kadetów i niepiśmiennych chłopów, jednakże, co najważniejsze, nie będziemy w stanie ocenić, czy rewolucja wybuchła, bo był głód, zagrożenie

${ }^{8}$ A. de Tocqueville: Dawne rzady..., s. 19.

9 V. Havel: Trzy lata - dzieje dramatu. Tłum. A.S. Jagodziński. „Gazeta Wyborcza” 1993, nr 54, s. 10.

${ }^{10}$ J. Baszkiewicz: Wolność, równość, własność: rewolucje burżuazyjne. Warszawa 1981. 
wojną czy lektura Kapitatu11. Podobnie jak lektura Woltera miała wpływ na rewolucję francuską (lub cała tradycja Oświecenia), ale trudno to skalować. Bliska jest nam w tej kwestii konkluzja wyrażona przez José Ortegę y Gasseta stwierdzającego: ,[...] w wyniku trzech stuleci humanizmu, historycy mają skłonność, aby umieszczać grupy intelektualne i artystyczne na zbyt eksponowanym planie, co fałszuje prawdziwy obraz sił historycznych"12. Następnie, odnosząc się do genezy rewolucji francuskiej, szkicuje hiszpański filozof kapitalną scenkę, kiedy to historyk Johannes von Müller reaguje na ustalony dogmat, wedle którego to philosophes wywołali rewolucję francuską: „Proszę mi uwierzyć, nie twierdzę, że muchy, które obsiadły dyszel naszego powozu, a pod których nazwą kryją się paryskie pięknoduchy, nie brzęczały strasznie, ale to nie one wywróciły powóz - po prostu woźnica zasnął!"’3. Odmienne stanowisko zajmuje Tocqueville, stwierdzając: „Okoliczność, że całe wychowanie polityczne narodu było wykonane przez literatów, zjawisko zupełnie nowe w dziejach, było może główną przyczyną, która nadała rewolucji francuskiej jej odrębny charakter"14.

Konkludując powyższy ustęp, chcemy wyraźnie podkreślić, że nie podcinamy gałęzi, na której siedzimy, a jedynie staramy się o właściwe rozłożenie akcentów. W rzeczy samej jesteśmy bowiem przekonani o sprawczej sile idei, problemem jest jedynie właściwe oddanie związku przyczynowo-skutkowego. Ów związek ma również ciąg dalszy, to znaczy, da się przedstawić jako: idea rewolucja - idea. W przypadku wielkich rewolucji mamy do czynienia z czasem fanatycznie zamierzonym a jednocześnie jakby mimowolnym apostolstwem idei. Szczególnie wyraźne jest to w przypadku rewolucji bolszewickiej, w której wystąpienie antycarskie miało być jedynie preludium do rewolucji powszechnej. Chodziło o totalną przemianę świata a nie jedynie Rosji1'.

Wprowadzeniem do kolejnej części naszego artykułu będzie fragment kończący przywoływaną już pracę A. de Tocqueville'a — Dawne rządy i rewolucja. Syntetyzując swoje przemyślenia dotyczące genezy rewolucji, odnosi się francuski pisarz do charakteru narodowego, bez zrozumienia to którego nie sposób wyrazić pogłębiony sąd o zaistniałych wydarzeniach. Czytamy: „Czy istniał kiedy na ziemi naród, tak pełen sprzeczności w czynach swoich, powodujący się

11 Pitirim Sorokin będący członkiem Partii Socjalistów-Rewolucjonistów i oglądający rewolucję z bliska w swojej socjologicznej analizie tego zjawiska kwestii ideowych w ogóle nie wymienia. Wskazywana represja instynktów wolności lub własności odnosi się do kwestii czysto praktycznych (cenzura, sądy wojenne, zubożenie, spekulacja itp.). Zob. P. Sorokin: The Sociology of Revolution. New York 1967, s. 367 i nast.

12 J. Ortega y Gasset: Bunt mas $i$ inne pisma socjologiczne. Przeł. P. Niklewicz, H. Woźniakowski, wstęp J. Szacki, wybór S. Cichowicz. Warszawa 1982, s. 696.

${ }^{13}$ Ibidem, s. 697.

${ }_{14}$ A. de Tocqueville: Dawne rzady..., s. 122.

15 Por. F. Furet: Przeszłość pewnego złudzenia. Tłum. J. Górnicka-Kalinowska, M. Ochab. Warszawa 1996, s. 15 i nast.; J.M. Bocheński: Lewica, religia, sowietologia. Warszawa 1996, s. 80 i nast. 
raczej uczuciem, niż zasadami, postępujący zawsze gorzej lub lepiej, niż można się było spodziewać; to spadający poniżej poziomu ludzkości, to go przewyższający [...] bezwładny i ociężały, dopóki pozostawiony sobie, a gotów iść na koniec świata i na wszystko odważyć, gdy go oderwą od jego domu i nawyknień; krnąbrny z natury, a łatwiej poddający się samowolnej i gwałtownej władzy pana, niż wolnym, opartym na prawach rządom obywatelskim [...]; zdatny do wszystkiego, lecz odznaczający się tylko na wojnie; wielbiciel przypadku, siły, powodzenia, świetności i szumu, więcej niż prawdziwej sławy; zdolniejszy do bohaterstwa niż do cnoty, do genialności niż do zdrowego rozumu [...]"16.

Fragment dotyczący Francuzów mógłby z powodzeniem służyć za charakterystykę Polaków. Nie chcąc się w tym miejscu zagłębiać w metodologiczne spory, na ile pewne przekazy źródłowe są stereotypami generującymi kolejne stereotypy, a na ile socjologicznym obrazem uproszonym, ale jednak przekazującym istotną prawdę, stwierdzimy, że w naszej ocenie rewolucje mają dosyć wyraźnie zaznaczone symptomy narodowości. W obfitej literaturze przedmiotu zjawisko to jest jednak stosunkowo słabo opisane, co chyba należy tłumaczyć faktem, że synteza i znalezienie uniwersalnych formuł wyjaśniających zjawiska społeczne jest wyżej cenione niż analiza lokalnych odniesień.

Jeśli nawet pobieżnie spojrzymy na teksty polskich myślicieli, polityków, działaczy i pisarzy w XIX i na początku XX w., to w zdecydowanej większości są one apologią powstań, wystąpień zbrojnych, walki, rewolucji itp. Romantyczna tradycja tworzy zarówno model kultury, kreuje bohaterów zbiorowej wyobraźni, jak również nadają narodowy rys polskiej religijności. Byronowska fraza z Giaura: „Walka o wolność, gdy raz się zaczyna / Z ojca krwią spada dziedzictwem na syna" ${ }^{\prime 17}$ na trwałe wpisuje się w naszą kulturę. Pojawiające się alternatywne wizje są traktowane jak nawoływanie do zdrady.

W tym samym czasie będący w analogicznej sytuacji naród czeski wytwarza zupełnie odmienny model kultury narodowej, w której praca i przeżycie są wartościami nadrzędnymi ${ }^{18}$. Rewolucja dla Czechów to bardziej kwestia psychologiczna aniżeli militarna. Od czasów Karola Hawliczka czytamy o „rewolucji głów i serc" 19 . To właśnie ten czeski działacz na łamach wydawanego przez siebie czasopisma zaszczepił rodakom wiarę w inny model rewolucji: „Dawniej mężowie umierali za cześć, dla dobra swojego narodu: my natomiast $\mathrm{z}$ tej samej przyczyny będziemy żyć i pracować" ${ }^{20}$. O wiele skuteczniejszą metodą działań

${ }^{16}$ A. de Tocqueville: Dawne rzady..., s. 165-166.

${ }_{17}$ G.G. Byron: Giaur. Przeł. A. Mickiewicz. Kraków 2003, s. 17.

${ }^{18}$ Szerzej A. Łuszczyński: Myśl polityczno-prawna Tomasza G. Masaryka jako rodzaj mitu państwotwórczego. Rzeszów 2013, s. 291-308.

${ }^{19}$ K. Havliček: Revoluce. V: Idem: Slovan, časopis věnovaný politickým a vi̊bec veřejným záležitostem slovanským, zvláště českým. Kutná Hora 1851, s. 147.

${ }^{20}$ T.G. Masaryk: Naše nynějši krise: pád strany staročeské a počátkové směrů nových. V: Idem: Česká otázka. Naše nynějši krize. Jan Hus. Praha 2000, s. 249. 
politycznych niż rewolucja jest opór prawny ${ }^{21}$. Następnie argumentacja czeskiego publicysty zostaje przejęta i wzbogacona przez Franciszka Palackiego uznającego, iż mały naród musi myśleć o zupełnie innej taktyce politycznej aniżeli przemoc. W przedmowie do jego dzieł czytamy: „Jest nas pięć milionów, otoczonych zewsząd nieprzyjaciółmi; ale nawet gdyby nas było pięćdziesiąt milionów, jednomyślnych, nie śmiałbym nawoływać [do przemocy]"22. Tym samym czeski program narodowy na długie lata zostaje zdeterminowany przez wystąpienia na forum parlamentarnym i pracę organiczną. Co istotne, nawet pojawienia się na czeskiej scenie politycznej T. Masaryka, który zasadniczo odrzucił taktykę Staroczechów i spowodował w czeskim społeczeństwie radykalny wstrząs, nie zmieniło podejścia do rewolucji. Na marginesie można dodać, że ów paradygmat pozytywistyczny nie został zanegowany ani podczas okupacji niemieckiej, ani w latach 1945-1946, ani w roku 1968, ani w roku 1989.

O ogromnym wpływie poglądów T. Masaryka na czeskie społeczeństwo napisano już wiele. W tym miejscu ogólnikowo stwierdzimy, że jest on nie do przecenienia i właściwie niemal każda idea polityczna wyrażona w Czechach w XIX czy XX w. musiała się do niego odnieść. Jak zostało nadmienione, samego Masaryka można traktować jak rewolucjonistę, tak zresztą jest często postrzegany. Milan R. Štefánik pisał: „W tym ogromnym chaosie, kiedy rządy i państwa tak niezmiernie się myliły [...], Masaryk pozostaje niezachwiany, widzi jasno cel i metodę. On pierwszy wiedział, co mają Czesi robić, wywołał rewolucję przeciwko Austrii"'23.

Oczywiście rewolucja występuje u Masaryka w różnych znaczeniach, czego on sam ma świadomość ${ }^{24}$. W Kwestii społecznej pisał: „Rewolucja a rewolucja! Brzmi ze wszystkich stron - rewolucja społeczna i ekonomiczna, rewolucja polityczna i filozoficzna, rewolucja literacka i naukowa... rewolucja! Co to znaczy? Co znaczy, że Francja od wielkiej rewolucji ośmiokrotnie zmieniła swoją konstytucję i przeżyła dziewięć rewolucji?"25. Jak zostało nadmienione, rewolucja jako taktyka polityczna została przez Masaryka odrzucona już na początku jego

${ }^{21}$ Patrz K. Havliček: Př́klad zákonného odporu. V: Idem: Slovan, časopis věnovaný politickým a vůbec veřejným záležitostem slovanským, zvláště českým. Kutná Hora 1851, s. 7-14; Idem: Revoluce..., s. 145-149; Idem: Uzavžení revoluce. V: Idem: Slovan..., s. 114-117.

${ }^{22}$ F. Palacký: Radhost III: spisy z oboru politiky. Praha 1873, s. 300; T.G. Masaryk: Naše nynějši krise..., s. 252.

${ }^{23}$ Z rozhovoru s dr. Vondrákem w Petrohradě dne 17. unora 1917 - podle českého zápisu prof. F. Piseckého. V: T.G.M. jak jsme ho viděli. Praha 1948, s. 11.

${ }^{24}$ Większe fragmenty krytyczne dotyczące rewolucji znajdziemy w Kwestii społecznej, Naszym obecnym kryzysie oraz Rosji i Europie. Zob. T.G. Masaryk: Otázka sociální. Vol. 2. Praha 2000, s. 175 i nast.; Idem: Naše nynějši krise..., s. 245 i nast.; Idem: The Spirit of Russia. Vol. 1. London 1968, s. 170 i nast., 450 i nast.; Idem: The Spirit of Russia. Vol. 2. London 1968, s. 332 i nast., 362 i nast., 528 i nast. Powtórzenie argumentacji: Idem: Zwycięstwo idei wolnościowej narodu. Warszawa-Poznań-Kraków-Stanisławów [ca 1930], s. 655 i nast.

25 T.G. Masaryk: Otázka sociální. Vol. 2..., s. 194. 
działalności publicznej. Jeszcze w czasach funkcjonowania monarchii habsburskiej, formułując swój program narodowy, czeski filozof postawił na powolny, konsekwentny, przemyślany rozwój kulturalny, kosztem „widowiskowych”, lecz niepraktycznych wystąpieńn ${ }^{26}$. Słusznie zatem pisze Kwietniowski, iż: „,Rewolucję Masaryk odrzuca jako niepraktyczny romantyzm" ${ }^{27}$. Sam Masaryk taktykę walki rewolucyjnej określił jako „utopijną”, zaś „,rewolucjonista to zazwyczaj polityk - fantasta”28. Uzasadnienie było następujące: „Człowiek nowocześnie wykształcony rozumie, że społeczeństwo rozwija się krokiem, nie skokiem, tak jest we wszystkich dziedzinach, zatem i w polityce [...]. Jest zatem przeciwko wszelkiej rewolucji [...]. Taktyka rewolucyjna jest przestarzała, jest zacofaniem. Realistyczne i konkretne pojmowanie społeczeństwa i państwa wyklucza polityczny romantyzm; realizm i rewolucja są opozycją. Kto wierzy w rewolucję, nie traktuje życia poważnie. Wiem, że rewolucja jest dziś przeżytkiem starego reżimu - polityka demokratyczna i ludowa rewolucji nie dopuści" ${ }^{29}$. Masaryk, by wzmocnić argumentację antyrewolucyjną, pisze, iż „Marks i Engels już poprawili swój pogląd na rewolucję [...] dostrzegając w machinie, więc ostatecznie w wynalazczości, w technice, w wiedzy i w pracy, najistotniejszą i najskuteczniejszą rewolucję społeczną, a zdecydowali się na parlamentaryzm" ${ }^{30}$. Masarykowa etyka pracy, wzmocniona argumentacją humanistyczną oraz koncepcją demokracji, konsekwentnie przeciwstawiała się poglądom tych czeskich środowisk, które próbowały forsować rozwiązania radykalne. W takich przypadkach nieustannie powtarzał: „radykalizm i reakcjonizm są politycznym dyletanctwem”. Program pracy pozytywnej miał być daleko skuteczniejszym narzędziem osiągania celów politycznych: „Świat stał i stoi na pracy, nie na humorach, świat się utrzymuje jedynie pracą i to pracą drobną, pracą stałą. [...] Polityka ludowa jest stałą i nieprzerwaną reformacją - polityka ludowa jest zapałem do pracy"31.

To właśnie pozytywistyczna praca jest gwarantem rzeczywistego postępu, jest prawdziwą zmianą społeczną, zaś to, co proponują Marks i jego wyznawcy, jest „dreptaniem w miejscu”, ich „,rewolucja jest kołtuństwem”32. Masaryk pisze: „Wiem bardzo dobrze, jak się wciąż sądzi na ten temat. Od dawna

${ }^{26}$ Podobnie M. Dokulil: Evoluce, či revoluce, jako média „spásonosného” rešení sociální otázky. V: T.G. Masaryk a sociální otázka. Sborník př́spěvků z 9. semináře Masarykova muzea $v$ Hodoníně 14. listopadu 2001. Edit. T. Martonova. Hodonín 2002, s. 33-49.

27 A.J. Kwietniowski: T.G. Masaryk. Życie i dzieło. Frysztat 1926, s. 89.

28 T.G. Masaryk: Otázka sociální. Vol. 2..., s. 195.

${ }^{29}$ Idem: Naše nynějši krise..., s. 200-201. Przy korekcie kolejnego wydania książki, w roku 1908 Masaryk dodał, że „rewolucja reformatorska jest usprawiedliwiona; bez takich rewolucji nie dokonały by się dobre, postępowe zmiany”.

${ }^{30}$ Idem: Zwycięstwo idei..., s. 656.

${ }^{31}$ Idem: Naše nynějši krise..., s. 201.

${ }^{32}$ K. Čapek: Hovory s T.G. Masarykem. Praha 1946, s. 73. Jest to autorskie przetworzenie hawliczkowego stwierdzenia: „Rewolucja każda jest sama w sobie nieszczęściem [...]”. K. Havliček: Revoluce..., s. 148. 
w opinii powszechnej panuje pogląd, że rozwój ludzkości bez przelewu krwi jest niemożliwym, że społeczeństwa są budowane krwią i żelazem, i tak dalej. [...] To, że się przelewała i przelewa krew, jest faktem; ale chodzi o to, jak dokonać postępu [...], aby przelanej krwi było coraz mniej? [...] chodzi o to, czy ta krew ma się przelewać nadal"? ${ }^{33}$. Na postawione pytanie Masaryk udzielał odpowiedzi negatywnej. Jego zdaniem przemoc nie jest właściwym środkiem dla osiągnięcia postępowych celów. Taka rewolucja jest ,jedynie zmianą, często zmianą na gorsze [...]. Po rewolucji następuje naturalna reakcja. Jaka rewolucja, taka reakcja i vice versa" ${ }^{34}$. Ten sam pogląd wyrażał w innym swoim dziele, nieco innymi słowami: „Historia [...] i życie każdego pouczają nas dostatecznie, że przemoc rewolucyjna nie obroni wolności, wręcz przeciwnie, że jej szkodzi. Wielkim tego dowodem jest francuska rewolucja. To wie dzisiaj każdy, kto zna historię ${ }^{35}$. [...] jedynie rewolucja poglądów i moralności jest rewolucją, przemoc niszczy rewolucję i wstrzymuje. Gwałtowna rewolucja jest zawsze reakcją i nigdy nie przysłużyła się prawdziwej wolności" ${ }^{36}$.

Istotnym argumentem przeciwko rewolucji była konstatacja, że w istocie nie tworzy ona niczego nowego ani w sferze ideowej, ani tym bardziej materialnej. To właśnie brak pierwiastka pozytywnego rewolucji, który mógłby służyć prostemu człowiekowi, sprawia, że jest ona niedopuszczalna. Masaryk pisze: „Rewolucja polityczna była arystokratycznym sportem, robili ją zawsze wielcy panowie, w jednej chwili bijąc się, a w drugiej pijąc i gaworząc - niewykształcone masy ludu pracowały dla nich [...] i stawiały im barykady [...]"37. Dzisiejszy lud „nie da się gnać w ogień” rewolucji, a jednocześnie nie znajdą się ,prawdziwie postępowi politycy, którzy by głosili śmierć”, jaką w istocie jest każdy karnawał przemocy. Wątek rewolucji jako próby instrumentalnego traktowania jednostek jest u Masaryka stale obecny, ulega jedynie wzmocnieniu pod wpływem obserwowanej praktyki w rewolucyjnej Rosji. Już w 1895 r. Masaryk żywi silne przeświadczenie, że rewolucja jest próbą wykorzystania prostych, nieuświadomionych ludzi do realizacji celów „fałszywych przywódców”. Jednak postępujący proces wykształcenia politycznego społeczeństw, skutecznie temu ma przeciwdziałać ${ }^{38}$. Pisząc w Rosji i Europie o rewolucji rosyjskiej 1917 r., wskazuje Lenina jako osobę chcącą wykorzystać rosyjskich proletariuszy dla zainicjowania „rewolucji powszechnej”, nie zaś polepszenia ich życia czy wyzwolenia od ucisku ${ }^{39}$. Podobnie w Wojnie o wolność narodów czytamy: „W 1917 roku

33 T.G. Masaryk: Naše nynějši krise..., s. 250.

${ }^{34}$ Idem: Otázka sociální. Vol. 2..., s. 195.

${ }_{35}$ Masaryk napisał na ten temat artykuł: Kult Rozumu a Nejvyšši bytosti (1793-1794). „Naše doba” 1894, č. 1.

36 T.G. Masaryk: Naše nynějši krise..., s. 246-247.

${ }^{37}$ Ibidem, s. 248.

${ }^{38}$ T.G. Masaryk: Naše nynějši krise..., s. 248.

${ }^{39}$ Idem: The Spirit of Russia. Vol. 2..., s. 590 i nast. 
Leninowi nie szło właściwie o urzeczywistnienie zasad komunizmu w Rosji, lecz o użycie Rosji w celu urzeczywistnienia, a przynajmniej przyśpieszenia urzeczywistnienia tych ideałów w Europie" ${ }^{\prime 40}$.

Posiłkowy argument przeciwko rewolucji można określić mianem „technicznego", gdyż Masaryk jest przekonany o bezsensowności tej formy walki ze względów praktycznych, powiązanych z postępem. „Jeszcze w roku 1848 wojsko miało takie karabiny i działa, że mogło do walczących strzelić raz, dwa razy, ale nie więcej - potem musieli nabijać, a w tym czasie masy ludu do nich dobiegały i zaczynała się walka wręcz. Zwycięstwo było po stronie silniejszej i bardziej bitnej. Dzisiaj przy broni szybkostrzelnej i liczebności wojska [...] rewolucja w miastach jest niemożliwa. [...] rewolucje i barykady istnieją jedynie w głowach zacofanych fantastów”"41. Rewolucja jest możliwa na wsi, „ale jedynie do momentu, gdy dojedzie tam wojsko"42.

Sprzeciw Masaryka wobec pewnego typu rewolucji jest logicznym następstwem jego własnej teorii demokracji, zawierającej w sobie określoną wizję postępu $^{43}$. Uznawał on, że „rozwój postępuje wolno, krok za krokiem”"44. Jednocześnie Masaryk nie wątpi, że postęp jest cechą charakterystyczną historii, nawet jeśli możemy zaobserwować cykliczność jakichś procesów, to odbywa się ona na linii wznoszącej. Demokracja, w oczach czeskiego filozofa, jest w istocie pewnym wzorcem kultury politycznej, będącym w opozycji względem dawnych, teokratycznych form. Owo przewartościowanie postaw jest również „rewolucją”, ale innego typu, inaczej uskutecznioną.

Rewolucja październikowa falsyfikowała tezę, jakoby zbrojne wystąpienia nie miały szans powodzenia ${ }^{45}$. Karnawał przemocy, jaki miał miejsce przy okazji przejmowania władzy przez bolszewików, zostaje przez Masaryka zauważony

${ }^{40}$ Idem: Wojna o wolność narodów. Warszawa-Poznań—Kraków—Stanisławów [ca 1930], s. 251.

${ }^{41}$ Idem: Naše nynějši krise..., s. 248

${ }^{42}$ Ibidem. Owe problemy ,techniczne” związane z rewolucją były w tamtych czasach argumentem dosyć ważkim, gdyż pojawiają się również u innych autorów. L. Tołstoj, pisał: „Nie tylko paryski asfalt, którym zastąpiono bruk, uniemożliwił budowanie barykad podczas rewolucji w Paryżu, takie asfalty w ciągu drugiej połowy XIX wieku pojawiły sie we wszystkich gałęziach zarządu państw: policja tajna, szpiegostwo, przekupstwo prasy, drogi żelazne, telegrafy, telefony, więzienia, fortece, ogromne bogactwa, wychowanie młodego pokolenia i najważniejsze wojsko - są w rękach rządu”. L. Tołstoj: Do działaczy politycznych. Przekł. K. Juljan. Kraków 1906, s. 10.

${ }^{43}$ Por. J. Pechar: Smysl Masarykovy revoluce. V: Po cestách naléhavosti myšlení. Praha 1993 , s. $120-127$.

44 T.G. Masaryk: Rusko a Evropa. Vol. 2. Praha 1996, s. 292.

${ }^{45}$ Por. R. Vlček: Masarykovy reflexe ruské revoluce v únoru 1917. V: Tomáš Garrigue Masaryk a ruské revoluce. Sborník př́ispěvků z 5. ročníku semináře Masarykova muzea v Hodonínè 19. listopadu 1997. Edit. T. Martonová. Hodonín 1998, s. 48-58; R. Vlček: Ruské revoluce a T.G. Masaryk. Ke kořenům interpretace ruských revolucí v roce 1917 v českém prostředi. V: Interpretace ruské revoluce 1917. Edit. J. Hanuš, R. Vlček. Brno 2008, s. 9-26. 
i po wielokroć skrytykowany, jednakże nie zauważa on (lub świadomie to przemilcza), że w istocie zadany zostaje kłam jego tezie „zwycięstwa ducha nad materią" ${ }^{\text {"46 }}$. Enuncjacje czeskiego polityka na temat demokratyzacji jako „konieczności dziejowej” nie były potwierdzane przez fakty. Masaryk pisał: „Rosjanin do tej pory wierzy, że rewolucja przyniesie cuda, wierzy w sposób mistyczny, niekrytyczny. [...] Rosjanie bardzo łatwo zapominają, że ich celem nie jest rewolucja a demokracja" ${ }^{\text {"47 }}$.

Rosyjska rewolucja odbywała się według zupełnie innego paradygmatu, niż zakładał Masaryk. Dlatego też trudno było czeskiemu filozofowi znaleźć punkty styczne, pozwalające na ujęcie wydarzeń w Rosji w ramach własnej teorii. Trudno z tego powodu czynić mu zarzut, gdyż rewolucja październikowa, szczególnie jej przebieg i długotrwałe skutki, były zaskoczeniem dla całej Europy i świata, przez co można mówić o nowej jakości w dziejach. Masaryk zgodnie ze swoimi postulatami badawczymi starał się rewolucję bolszewicką „racjonalizować”, kiedy w rzeczywistości rządziła się ona własną „logiką" unikalną i bez odniesień do rewolucji znanych z przeszłości, przez co była irracjonalna. Trwałość i krzepnięcie „dorobku” porewolucyjnej Rosji sprawiały, że argumenty kładące nacisk na efemeryczność i utopijność leninowskich koncepcji traciły rację bytu, stając się z każdym rokiem istnienia państwa swoją własną karykaturą. Jednocześnie propaganda „nowego, wspaniałego świata” malowała w niemalże całej Europie wizje sprawiedliwego państwa robotników i chłopów, znajdując entuzjastów. Wówczas Masaryk zaczyna kwestionować tożsamość ustroju wprowadzanego w Rosji. W przemówieniu do czeskich robotników stwierdza: ,[...] zaznaczam jednak, że w Rosji nie ma komunizmu, ani nawet socjalizmu, z tej prostej przyczyny, że naród rosyjski nie jest przygotowany do przyjęcia socjalizmu. [...] Rosjanie są narodem wielkim i licznym, lecz, niestety, nie umieją czytać i pisać, są mniej wykształceni [od Czechów], stoją na niższym stopniu kultury niż wy. A więc wszystko co u siebie robią, nabiera swoistego charakteru; tak jest także z ich tak zwanym komunizmem. Mówiłem wam już: nie ma w Rosji komunizmu w życiu, jest tylko na papierze. Rosja — to chłopi, a w chłopstwie nie ma komunizmu, chłopstwo - to własność prywatna"48. Po raz kolejny powraca wątek pracy jako opozycji względem nieprzemyślanych wybuchów przemocy ${ }^{49}$. Tworzy to sygnalizowane już rozgraniczenie rewolucji właściwej i formy ,arystokratycznej”, zdegenerowanej: „Bolszewicy jednak nie potrafili i nie potrafią pracować, potrafią tylko zmuszać do pracy — ustrój bolszewicki wprowadził

46 T.G. Masaryk: Wojna o wolność..., s. 248-249.

${ }^{47}$ Idem: Rusko a Evropa..., s. 675.

${ }^{48}$ T.G. Masaryk: O bolszewiźmie. Warszawa [1922], s. 18-19. Z kolei w Wojnie o wolność narodów, pisze: „Bolszewizm więcej zbliża się do Bakunina niż do Marxa”. T.G. Masaryk: Wojna o wolność..., s. 254.

${ }^{49}$ Podobnie D. Kovač: World Revolution - Tomas Garrigue Masaryk and Vladimir Ilyich Lenin. „Human Affairs” 1991, No. 1, s. 22-29. 
bowiem niewolnictwo burżuazji i to burżuazji określonej bardzo dowolnie, tak bardzo dowolnie, że wprowadzono właściwie niewolnictwo robotników — bolszewicy potrafią walczyć, zabijać i umierać, nie potrafią jednak obowiązkowo, stale i systematycznie pracować. Rewolucja bolszewicka była i jest wobec tego rewolucją polityczną a nie społeczną ani ekonomiczną"50.

Stosunek Masaryka do rewolucji, w warunkach Republiki, miał wymiar praktyczny — chodziło o niedopuszczenie rozprzestrzeniania się wrogiej ideologii i pozyskanie czeskiego społeczeństwa dla własnej demokracji i humanity ${ }^{51}$. Zatem w przemówieniu Prezydent-Oswobodziciel stwierdzał: „Tłumaczy się wojną i jej anarchią, że tak jak gdzie indziej, tak i u nas wielu popiera plany jakiejś cudownej rewolucji. Ja sam w rewolucji uczestniczyłem i ją prowadziłem, ale ta rewolucja była przygotowywana pokoleniami, przygotowywana długim wychowaniem politycznym. Ani przez chwilę nie zapomniałem, że po rewolucyjnym uniesieniu ludzie powrócą do starych praktyk, przyzwyczajenie jest drugą naturą człowieka" 52 . Podobne słowa padły podczas wizyty formowanego w Rosji pułku Legii: „Zatem nowy porządek. Mieć prezydenta, to jeszcze nie wszystko. Chodzi o ducha, kiedy mówimy „odaustriaczyć”. To się łatwo mówi, ale to oznacza - być nowym człowiekiem, to dotyczy każdego z nas. Nie da się tego zrobić w sposób mechaniczny, to musi być przemiana natury, przyzwyczajeń. Nie mogę wam rzec niczego innego, niż to byście dogłębnie przemyśleli ową zmianę, abyście jej pragnęli’’53. Nowy człowiek, o którym mówił Masaryk, miał być wynikiem pracy każdego obywatela nad sobą samym, nie zaś, jak miało to miejsce $w$ innych rewolucjach, inżynierii społecznej ${ }^{54}$.

Ograniczone ramy artykułu nie pozwalają na snucie pogłębionych analiz, jednakże wydaje się, że uprawnione jest stwierdzenie, iż rewolucje posiadają rys narodowy, mogący przejawiać się $\mathrm{w}$ różnych formach. Jest to jednocześnie temat stosunkowo słabo spenetrowany przez badaczy i zasługujący na uwagę. Ciekawe są zarówno przyczyny determinujące podejście narodów do problemu gwałtownej zmiany społecznej (religia, historia, ekonomia itp.), jak również sama konkretyzacja problemu.

50 T.G. Masaryk: $O$ bolszewiźmie..., s. 39-40.

${ }^{51}$ Masaryk wyraźnie stwierdzał: „Nie możemy rosyjskich stosunków przenosić na stosunki nasze”. Idem: Řeč při návštěvě prvního plku ruských legii Mistra Jana Husi. V: Idem: Cesta demokracie. Soubor projevů za Republiky 1918-1920. Vol. 1. Praha 1939, s. 292.

${ }^{52}$ Idem: Národnímu Shromážděni a vláde. V: Idem: Cesta demokracie..., s. 273.

${ }^{53}$ Idem: Řeč při návštěvě prvního plku..., s. 292.

${ }^{54}$ Por. J. Zouhar: Otázka revoluce u T.G. Masaryka. V: Tomáš Garrigue Masaryk a ruské revoluce..., s. $1-3$. 


\section{Bibliografia}

Arendt H.: O rewolucji. Przeł. M. Godyń. Kraków 1991.

Baszkiewicz J.: Wolność, równość, własność: rewolucje burżuazyjne. Warszawa 1981. Bocheński J.M.: Lewica, religia, sowietologia. Warszawa 1996.

Byron G.G.: Giaur. Przeł. A. Mickiewicz. Kraków 2003.

Čapek K.: Hovory s T.G. Masarykem. Praha 1946.

Czajkowski W.: O pewnych poznawczych pożytkach płynacych z wieloznaczności słowa „rewolucja”. W: O rewolucji. Obrazy radykalnej zmiany społecznej. Red. K. Brzechczyn, M. Nowak. Poznań 2007.

Dokulil M.: Evoluce, či revoluce, jako média ,spásonosného” řě̌eni sociální otázky. V: T.G. Masaryk a sociálni otázka. Sborník př́spěvků z 9. semináře Masarykova muzea v Hodoníně 14. listopadu 2001. Edit. T. Martonova. Hodonín 2002.

Furet F.: Przeszłość pewnego złudzenia. Tłum. J. Górnicka-Kalinowska, M. Ochab. Warszawa 1996.

Havel V.: Trzy lata - dzieje dramatu. Tłum. A.S. Jagodziński. „Gazeta Wyborcza” 1993, nr 54.

Havliček K.: Př́klad zákonného odporu. V: Idem: Slovan, časopis věnovaný politickým a vůbec veřejným záležitostem slovanským, zvláště českým. Kutná Hora 1851.

Havliček K.: Revoluce. V: Idem: Slovan, časopis věnovaný politickým a viobec veřejným záležitostem slovanským, zvláště českým. Kutná Hora 1851.

Kovač D.: World Revolution - Tomas Garrigue Masaryk and Vladimir Ilyich Lenin. „Human Affairs” 1991, nr 1.

Kwietniowski A.J.: T.G. Masaryk. Życie i dzieło. Frysztat 1926.

Le Bon G.: Psychologia tłumu. Tłum. B. Kaprocki. Kęty 2013.

Łuszczyński A.: Myśl polityczno-prawna Tomasza G. Masaryka jako rodzaj mitu państwotwórczego. Rzeszów 2013.

Masaryk T.G.: Kult Rozumu a Nejvyšši bytosti (1793-1794). „Naše doba” 1894, nr 1.

Masaryk T.G.: Národnímu Shromáždění a vláde. V: Idem: Cesta demokracie. Soubor projevio za Republiky 1918-1920. Vol. 1. Praha 1939.

Masaryk T.G.: Naše nynějši krise: pád strany staročeské a počátkové směrů nových. V: Idem: Česká otázka. Naše nynější krize. Jan Hus. Praha 2000.

Masaryk T.G.: O bolszewiźmie. Warszawa [1922].

Masaryk T.G.: Otázka sociální. Vol. 1-2. Praha 2000.

Masaryk T.G.: Rusko a Evropa. Vol. 2. Praha 1921.

Masaryk T.G.: Ǩeč při návštěvě prvního plku ruských legii Mistra Jana Husi. V: Idem: Cesta demokracie. Soubor projevů za Republiky 1918-1920. Vol. 1. Praha 1939.

Masaryk T.G.: The Spirit of Russia. Vol. 1-3. London 1968.

Masaryk T.G.: Wojna o wolność narodów. Warszawa-Poznań-Kraków-LwówStanisławów [ca 1930].

Masaryk T.G.: Zwycięstwo idei wolnościowej narodu. Warszawa-Poznań-Kraków-Lwów-Stanisławów [ca 1930].

Mill J.S.: Utylitaryzm. O wolności. Wstęp T. Kotarbiński. Kraków 1959. 
Národnímu Shromáždění a vláde. V: T.G. Masaryk: Cesta demokracie. Soubor projevi za Republiky 1918-1920. Vol. 1. Praha 1939.

Ortega y Gasset J.: Bunt mas $i$ inne pisma socjologiczne. Przeł. P. Niklewicz, H. Woźniakowski, wstęp J. Szacki, wybór S. Cichowicz. Warszawa 1982.

Palacký F.: Radhost III: spisy z oboru politiky. Praha 1873.

Pareto V.: Uczucia i działania. Fragmenty socjologiczne. Przeł. M. Dobrowolska, M. Rozpędowska, A. Zinserling, wybór, wstęp i red. A. Kojder. Warszawa 1994.

Pechar J.: Smysl Masarykovy revoluce. V: Po cestách naléhavosti myšlení. Praha 1993. Řeč při návštěvě prvního plku ruských legii Mistra Jana Husi. V: T.G. Masaryk: Cesta demokracie. Soubor projevi̊ za Republiky 1918-1920. Vol. 1. Praha 1939.

Sorokin P.: The Sociology of Revolution. New York 1967.

Tocqueville A., de: Dawne rzady i rewolucja. Przekł. W.M. Kozłowski. Warszawa 2003.

Tocqueville A., de: O demokracji w Ameryce. Przeł. M. Król, wstęp J. Baszkiewicz. Warszawa 1976.

Tołstoj L.: Do działaczy politycznych. Przekł. K. Juljan. Kraków 1906.

Vlček R.: Masarykovy reflexe ruské revoluce v únoru 1917. V: Tomáš Garrigue Masaryk a ruské revoluce. Sborník př́spěvků z 5. ročníku semináře Masarykova muzea v Hodoníně 19. listopadu 1997. Edit. T. Martonová. Hodonín 1998.

Vlček R.: Ruské revoluce a T.G. Masaryk. Ke kořenưm interpretace ruských revolucí $v$ roce 1917 v českém prostředí. V: Interpretace ruské revoluce 1917. Edit. J. Hanuš, R. Vlček. Brno 2008.

Zouhar J.: Otázka revoluce u T.G. Masaryka. V: Tomáš Garrigue Masaryk a ruské revoluce. Sborník př́spěvků z 5. ročníku seminářre Masarykova muzea v Hodoníně 19 listopadu 1997. Edit. T. Martonová. Hodonín 1998.

$Z$ rozhovoru s dr. Vondrákem w Petrohradě dne 17. unora 1917 - podle českého zápisu prof. F. Piseckého. V: T.G.M. jak jsme ho viděli. Praha 1948.

Artur Łuszczyński, Małgorzata Łuszczyńska

\section{Bemerkungen zum universellen und nationalen Charakter der Revolution}

Schlüsselwörter: Revolution, Nation, gesellschaftlicher Wandel, Geschichte einer Idee

Zusammenfassung: Der Artikel klärt die definitorischen Probleme rund um den Begriff „Revolution“. Die Autoren stellen fest, dass Revolutionen, wie definierbar sie auch sein mögen, klare, erfassbare nationale Merkmale aufweisen. Die Analyse dieses Problems basiert auf polnischen und tschechischen Traditionen, weil diese beiden Nationen völlig unterschiedliche Herangehensweisen an das Thema Revolution vertreten. Die Zusammenstellung des tschechischen Konservatismus und Unglaubens an eine revolutionäre Strategie mit der polnischen Tradition der Unabhängigkeitsauflehnungen ist vom hohen Erkenntniswert und kann nach Ansicht der Autoren neue Forschungsfelder eröffnen. 
Artur Łuszczyński, Małgorzata Łuszczyńska

\section{Remarks on the universal and national character of the revolution}

Keywords: revolution, nation, social change, history of ideas

Summary: The article clarifies definitional problems concerning the term of revolution. The authors claim that revolutions, however defined, possess national features that are clear and possible to grasp. The analysis of the problem was conducted on the basis of Polish and Czech traditions, as these two nations present completely different approaches to the issue of revolution. According to the authors, Czech conservatism and their lack of belief in revolutionary strategies compared with Polish tradition of independence spurts create new and cognitively interesting areas of research. 
